\title{
Analysis of Amil Zakat Institution Performance Using the Balanced Scorecard Method (Case study in BAZNAS Sragen)
}

${ }^{1}$ Siti Khadijah dan Mufti Afif

Fakultas Ekonomi dan Manajemen Universtas Darussalam Gontor

\section{khadijah99@gmail.com \& alamjagatraya12@gmail.com}

ABSTRACT, The zakat funds collection, infaq and shadaqah movement in Sragen Regency was formally implemented by the Zakat Infaq and Shadaqah Agency (BAZIS) which was established on May 27, 1991. By the issuance of Law No. 38 of 1999 concerning Management of Zakat, it was changed to the National Zakat Agency (BAZNAS). Amil Zakat Agency (BAZ) Sragen has a number of special programs in introducing zakat to the community. Finally they were able to collect zakat funds of around Rp. 250 million per month. The zakat funds which are collected at the Sragen BAZ mostly come from civil servants, the TNI and the National Police. However, this program has not been optimal yet, zakat funds absorbed only around Rp. 2 billion per year from the potential of $R p$. 7 billion. Therefore, performance measurement is one of the important factors in companies and institutions to evaluate work results from the past period.

This research uses the Balance Scorecard paradigm / perspective, namely measurement using four perspectives; Finance, Customers, Internal Business, Learning and Growth. The method used is descriptive explorative qualitative method. Data was collected by interview, questionnaire and documentation.

The results showed that the performance of BAZNAS of Sragen Regency was "Good". The results of the average score of the performance appraisal of BAZNAS in Sragen Regency were 6: $8=0.75$ which is "Good".

Keywords: Performance, Balanced Scorecard

\section{A. Pendahuluan}

Potensi zakat di Indonesia sangat besar dengan bertambahnya kesadaran masyarakat membayar zakat. Yaitu mencapai Rp. 217,3 triliun setiap tahunnya. ${ }^{1}$ Penghimpunan zakat di Indonesia terkadang memerlukan strategi tersendiri agar masyarakat kian sadar

${ }^{1}$ Zakkaaha BAZNAS kabupaten Sragen, Sedekah dari masa ke masa, edisi 4 Vol 1 April 2015, p. 8 
mengenai kewajiban berzakat. ${ }^{2}$ Gerakan penghimpunan zakat, infaq dan shadaqah di Kabupaten Sragen secara formal dilaksanakan dengan pembentukan Badan Amil Zakat Infaq dan Shadaqah (BAZIS) Kabupaten Sragen pada tanggal 27 Mei 1991. Dengan terbitnya UU No 38 tahun 1999 tentang Pengelolaan Zakat, maka berubah menjadi Badan Amil Zakat Nasional (BAZNAS). Dengan Visinya untuk menjadi Badan Amil Zakat Nasional Kabupaten yang amanah dan profesional, serta mampu mengambil peran dalam meningkatkan kesejahteraan umat Islam di Kabupaten Sragen. ${ }^{3}$

Badan Amil Zakat (BAZ) Sragen pun menyiapkan sejumlah program khusus dalam memperkenalkan zakat kepada masyarakat. Hasilnya setiap bulan mampu mengumpulkan dana zakat sekitar Rp 250 juta. dana zakat yang terhimpun di BAZ Sragen sebagian besar berasal dari pegawai negeri sipil, TNI, dan Polri. Namun dari jumlah pegawai negeri sipil, TNI, dan Polri yang sekitar 13 ribu, dana zakat yang terserap baru sekitar Rp 2 miliar per tahun dari potensi

\footnotetext{
http://mysharing.co/baz-sragenhimpun-dana-zakat-rp-250-juta-per-bulan/ , Saturday, 4 June 2016. Diunggah pada 3:00 WIB. Op.cit, p.3
}

Rp 7 miliar. Sementara dari keseluruhan wilayah Sragen baru bisa menyerap sekitar 9 persen dari potensi yang ada. Hal tersebut disebabkan pula karena adanya sejumlah lembaga amil zakat yang beroperasi di kawasan Sragen. ${ }^{4}$

\section{Dalam kaitannya dengan} penguatan lembaga yang memiliki pesaing berupa lembaga amil zakat serupa, maka dibutuhkan manajemen zakat, infaq dan shadaqah yang professional agar tidak kalah dalam persaingan. Untuk itu lembaga seperti BAZNAS perlu perencanaan strategis dalam menjalankan organisasinya. Penilaian atau pengukuran kinerja merupakan salah satu faktor yang penting dalam monitoring keberhasilan perusahaan dan lembaga. ${ }^{5}$ Maka peneliti ingin menganilis kinerja Badan Amil Zakat Nasiona (BAZNAS) Kabupaten Sragen periode 2015 dengan menggunakan Balance Scorecard.

$4 \quad$ http://mysharing.co/baz-sragenhimpun-dana-zakat-rp-250-juta-per-bulan/ , Saturday, 4 June 2016. Diunggah pada 3:00 WIB.

5 Seviawati Polinggapo, Pengukuran Kinerja Lembaga Pengelolaan Zakat, Infaq dan Sedekah (ZIS) dengan menggunakan metode Balanced Scorecard (studi kasus pada Yayasan Dana Sosial Al-Falah Malang), (jurnal Akutansi Fakultas Ekonomi UIN Maliki Malang), p. 1-2 


\section{B. Landasan Teori}

1. Pengertian Zakat

Zakat merupakan salah satu kewajiban yang disyari'atkan Allah kepada umat Islam, sebagai salah satu perbuatan ibadah setara dengan shalat, puasa, dan ibadah haji. Akan tetapi, zakat tergolong ibadah maliah, yaitu ibadah melalui harta kekayaan dan bukan ibadah badaniyah yang pelaksanaannya secara fisik. Hal inilah yang membedakan zakat dengan ibadah ritual lainnya, seperti ibadah shalat, puasa dan haji yang manfaatnya hanya terkena pada individu itu sendiri. Sedangkan manfaat zakat bukan untuk individu, melainkan berfaat pula bagi orang lain. Allah mewajibkan zakat kepada individu yang mampu dengan tujuan mengetahui seberapa besar cinta hamba kepada penciptanya daripada dengan hartanya. ${ }^{6}$

Menurut istilah ekonomi, zakat merupakan tindakan pemindahan kekayaan dari golongan kaya kepada golongan yang miskin. Salah satu ajaran penting yang terdapat dalam agama islam adalah urgensi zakat kaitannya dengan pengentasan kaum dhu'afa dan mustadz'afin. Sebagai sebuah dinamika keagamaan, zakat merupakan bentuk

${ }^{6}$ M.Nur Rianto, Lembaga Keuangan Syari'ah, (Bandung : Pustaka Setia 2012), hal 375. kesaksian manusia pada rukun islam yang keempat dihadapan Allah yang muaranya tertuju pada dimensi kemanusiaan. ${ }^{7}$

2. Kinerja

Kinerja adalah gambaran mengenai tingkat pencapaian pelaksanaan suatu kegiatan/program/kebijakan dalam mewujudkan sasaran, tujuan, visi dan misi organisasi yang tertuang dalam Strategic Planing suatu organisasi. Istilah kinerja sendiri sering digunakan untuk menyebut prestasi atau tingkat keberhasilan individu maupun kelompok individu. Kinerja dapat diketahui hanya jika individu atau kelompok individu tersebut mempunyai kriteria keberhasilan yang telah ditetapkan. Kriteria keberhasilan ini berupa tujuan- tujuan atau target-terget tertentu yang hendak dicapai. Penilaian kinerja pada dasarnya merupakan kegiatan manusia dalam mencapai tujuan organisasi. Penilaian kinerja sebagian penentu secara periodik efektivitas operasional suatu organisasi, bagian organisasi, dan karyawan berdasarkan sasaran, standard dan kreteria yang telah ditetapkan sebelumnya. Karena organisasi pada dasarnya dioperasikan oleh sumber daya manusia maka penilaian kinerja

${ }^{7}$ Seviawati Polinggapo (jurnal akutansi Fakultas Ekonomi UIN Malang) op.cit, hal 2. 
sesungguhnya merupakan penilaian atas perilaku manusia dalam melaksanakan peran yang mereka mainkan dalam organisasi. ${ }^{8}$

Kinerja adalah istilah umum yang digunakan untuk menunjukkan sebagian atau seluruh tindakan atau aktivitas dari suatu organisasi pada suatu periode. ${ }^{9}$ Seiring dengan referensi pada sejumlah standar seperti biaya-biaya masa lalu atau yang di proyeksikan suatu dasar efisiensi, pertanggungjawaban atau akuntabilitas manajemen dan semacamnya. ${ }^{10}$ Kinerja adalah suatu tampilan keadaan secara utuh atas perusahaan selama periode waktu tertentu, merupakan hasil atau prestasi yang dipengaruhi oleh kegiatan operasional perusahaan dalam memanfaatkan sumber-sumber daya yang

\footnotetext{
${ }^{8}$ Achya Zaenul Huda, Analisis Kinerja dengan pendekatan Pendekatan Balance Scorecard (Studi kasus pdam Tirta Dharma Kabupaten Klaten), (Skripsi Fakultas Ekonomi dan Bisni Universitas Muhammadiyah Surakarta 2013), hal 4-5.
}

9 Utami Puji Lestari, Balanced Scorecard (Bsc) Sebagai Alat Pengukur Kinerja Manajemen Dalam Pengembangan Strategi Perusahaan, (jurnal Ebis, Volume 6 Nomor 2 Juli 2014), hal 125.

10 Seviawati polinggapo, Pengukuran Kinerja Lembaga pengelola Zakat, Infaq san sedekah (ZIS) dengan menggunakan metode Balanced Scorecard (Studi kasus pada Yayasan Dana Sosial Al-Falah Malang), (jurnal akutansi Fakultas Ekonomi UIN Maliki Malang), hal 3. dimiliki. ${ }^{11}$ Kinerja didefinisikan sebagai keberhasilan perusahaan atau personel dalam mewujudkan sasaran-sasaran strategik yang telah dirumuskan melalui inisiatif pilihan. $^{12}$ Syarat-syarat kinerja yang efektif : ${ }^{13}$

a. Didasarkan pada masing-masing aktivitas dan karakteristik organisasi itu sendiri sesuai dengan perspektif pelanggan;

b. Evaluasi atas berbagai aktivitas,

c. Sesuai dengan seluruh aspek kinerja aktivitas yang mempengaruhi pelanggan, sehingga menghasilkan penilaian yang komprehensif;

d. Memberikan umpan balik untuk membantu seluruh anggota organisasi mengenali masalah-masalah yang memungkinkan untuk diperbaiki.

Tahap-tahap sistem manajemen kinerja $:^{14}$

11 Endang Kiswara SE., M.Si., Akt., Analisis Balance Scorecard Sebagai Alat Pengukur Kinerja Perusahaan (Studi Kasus pada PT Astra Honda Motor), hal 4.

12 Mulyadi, Sistem terpadu pengelolaan kinerja personel berbasis Balanced Scorecard, (Yogyakarta, UPP STIM YKPN : 2009), hal viii

13 Utami Puji Lestari, Balanced Scorecard (Bsc) Sebagai Alat Pengukur Kinerja Manajemen Dalam Pengembangan Strategi Perusahaan, (jurnal Ebis, Volume 6 Nomor 2 Juli 2014), hal 126.

14 Mahmudi, manajemen kinerja sector public, (Yogyakarta, UPP STIM YKPN : 2010), hal 16-18. 
a. Tahap perencanaan kinerja

b. Tahap pelaksanaan kinerja

c. Tahap penilaian kinerja

d. Tahap review kinerja

e. Tahap perbaikan kinerja

\section{Balanced scorecard}

Balanced Scorecard adalah kartu yang digunakan untuk mencatat skor hasil kinerja seseorang yang berimbang antara dua aspek yaitu aspek keuangan dan non keuangan, jangka pendek dan jangka panjang, intern dan ekstern. Untuk itu ada 4 perspektif dalam membentuk kerangka kerja balanced scorecard yaitu financial, pelanggan, proses bisnis internal serta pembelajaran dan pertumbuhan. Balanced Scorecard lebih dari sekedar sistem pengukuran taktis atau operasional. Perusahaan yang inovatif menggunakan scorecard sebagai sebuah sistem manajemen strategis, untuk mengelola strategi jangka panjang. Perusahaan menggunakan fokus pengukuran scorecard untuk menghasilkan berbagai proses manajemen penting, yaitu Memperjelas dan menerjemahkan visi dan strategi, Mengomunikasikan dan mengaitkan berbagai tujuan dan ukuran strategis, Merencanakan, menetapkan sasaran, dan menyelaraskan berbagai inisiatif strategis.
Implementasi balance scorecard tergantung dari kebijakan organisasi. ${ }^{15}$ Konsep Balanced Scorecard telah lama dikembangkan oleh Robert S.Kaplan dan David P.Norton (HBR, January,1992). Konsep Balanced Scorecard ini dikembangkan untuk melengkapi pengukuran kinerja finansial (atau dikenal dengan pengukuran kinerja tradisional) dan sebagai alat yang cukup penting bagi organisasi perusahaan untuk merefleksikan pemikiran baru dalam era competitiveness dan efektivitas organisasi. Konsep ini memperkenalkan suatu sistem pengukuran kinerja perusahaan dengan menggunakan kriteria-kriteria tertentu. Kriteria tersebut sebenarnya merupakan penjabaran dari apa yang menjadi misi dan strategi perusahaan dalam jangka panjang, yang digolongkan menjadi empat perspektif yang berbeda yaitu : ${ }^{16}$

a. Perspektif finansial

Bagaimana kita berorientasi pada para pemegang saham.

15 Isniar Budiarti, Balanced Scorecard Sebagai Alat Ukur Kinerja Dan Alat Pengendali Sistem Manajemen Strategis, (jurnal majalah ilmiah Unikom, Vol 6 Universitas Komputer Indonesia Program studi Manajemen), hal 51.

16 Monika Kussetya Ciptani, Balanced Scorecard Sebagai Pengukuran Kinerja Masa Depan: Suatu Pengantar, (Jurnal Akuntansi \& Keuangan Vol. 2, No. 1, Mei 2000), hal 24. 
b. Perspektif customer

Bagaimana kita bisa menjadi supplier utama yang paling bernilai bagi para customer.

c. Perspektif proses bisnis internal Proses bisnis apa saja yang terbaik yang harus kita lakukan, dalam jangka panjang maupun jangka pendek untuk mencapai tujuan finansial dan kepuasan customer.

d. Perspektif pertumbuhan dan pembelajaran

Bagaimana kita dapat meningkatkan dan menciptakan value secara terus menerus, terutama dalam hubungannya dengan kemampuan dan motivasi karyawan.

\section{Metode Penelitian}

Metode yang digunakan adalah metode kualitatif deskriptif eksploratif, yang berupa studi kasus, dengan perincian sebagai berikut:

1. Objek Penelitian; adalah BAZNAS Sragen sebagai lembaga pengumpul dan pendistribusian dana zakat.

2. Metode Pengumpulan Data; data dikumpulkan dengan menggunakan metode wawancara, kuisioner dan dokumentasi, wawancara dilakukan dalam bentuk lisan kepada para Pegawai BAZNAS untuk mengetahui tingkat kepuasan kerja, sedangkan kuisioner dalam bentuk angket kepada Muzakki BAZNAS untuk mengetahui tingkat kepuasan Muzakki, dan dokumentasi dilakukan dengan cara mendokumentasikan dokumen dan literatur yang berhubungan dengan materi penelitian.

3. Prespektif Penelitian dalam pengolahan data; Pengukuran kinerja BAZNAS dengan Balanced Scorecard dilakukan dengan empat prespektif sebagai berikut:

\section{a) Prespektif keuangan}

Rumus $=\frac{\text { Realisasi Penerimaan }}{\text { Target Penerimaan }} \times 100 \%$

\section{b) Prespektif pelanggan}

1) Kemampuan pemerolehan muzakki (akuisi Muzakki) :

Rumus $=\frac{\text { Jumlah Muzakki Baru }}{\text { Total Muzakki }} \times 100 \%$

2) Kemampuan mempertahankan Muzakki (Retensi Muzakki) : Rumus $=\frac{\text { Jumlah Muzakki non aktif dalam } 1 \text { periode }}{\text { Total Jumlah Muzakki }} \times 100 \%$

3) Tingkat Kepuasan Muzakki

Untuk mengetahui tingkat kepuasan Muzakki dengan menggunakan kuesioner. 
Metode yang digunakan adalah quota sampling. Quota sampling adalah metode dimana peneliti mengklasifikasikan populasi berdasarkan kriteria-kriteria tertentu, kemudian mementukan proporsi sampel dari masing-masing kelas, lalu menetapkan kuota untuk masing-masing interviewer. ${ }^{17}$

Peneliti akan mengambil sampel dari Unit Pengumpulan Zakat BAZNAS Sragen, dilihat dari banyaknya dana zakat yang dihimpun, yaitu :

1) Kementrian Agama $20 \%=20$ Muzakki

2) PDAM

$$
20 \%=20 \text { Muzakki }
$$

3) Dinas Kesehatan

$$
15 \%=15 \text { Muzakki }
$$

4) Dinas Peternakan \& Perikanan

$$
15 \%=15 \text { Muzakki }
$$

5) KBPMD

$$
15 \%=15 \text { Muzakki }
$$

6) Dinas Pekerjaan Umum

$$
15 \%=15 \text { Muzakki }
$$

Tingkat kepuasan pelanggan yaitu mengukur seberapa jauh para pelanggan

17 Hendri tanjung dan abrista devi, Metode Peneltian Ekonomi Islam, (Jakarta: Gratama Publishing 2013), hal 117. merasa puas terhadap pelayanan perusahaan. Kepuasan konsumen mengukur rata-rata kepuasan pelanggan dengan memberikan nilai pada jawaban kuisioner sesuai dengan tingkat kepuasan yang dirasakan. Dari hasil penjumlahan seluruh nilai yang diperoleh dari seluruh responden akan diketahui pencapaian indeks kepuasan pelanggan, seperti yang dirumuskan Sugiyono sebagai berikut:

$$
\mathrm{IKK}=\mathrm{PP}
$$

\section{Dimana:}

$\mathrm{IKK}=$ indeks kepuasan konsumen $\mathrm{PP}=$ perceived performance

Setelah diketahui IKK dari seluruh responden kemudian digolongkan pada skala: a. sangat tidak puas, b. tidak puas, c. cukup puas, d. puas, e. sangat puas. Untuk menentukan nilai skala terlebih dahulu ditentukan ideks kepuasan minimal dan indeks kepuasan maksimalnya. Interval yang dapat dicari dari pengurangan antara indeks kepuasan maksimal dengan kepuasan minimal, kemudian dibagi menjadi lima. Dirumuskan oleh Sugiyono sebagai berikut:

$$
\begin{array}{ll}
\text { IK Maks } & =\mathrm{R} \times \mathrm{PP} \times \mathrm{EX} \text { maks } \\
\text { IK Min } & =\mathrm{R} \times \mathrm{PP} \times \mathrm{EX} \text { min } \\
\text { Interval } & =(\mathrm{IK} \text { maks }- \text { IK min })
\end{array}
$$

Dimana:

PP = banyak pertanyaan 


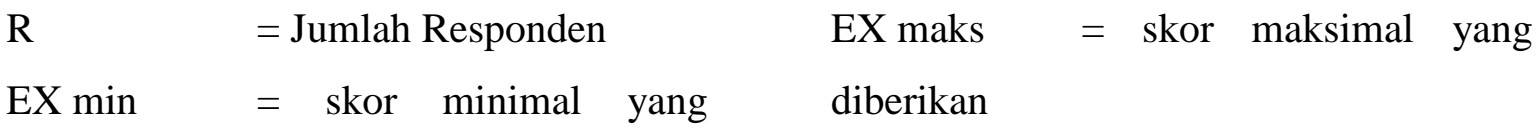
diberikan

c) Prespektif bisnis internal

1) Inovasi

$$
\text { Inovasi }=\frac{\text { Jumlah Realisasi Inovasi pada } 1 \text { Periode }}{\text { Target Inovasi pada } 1 \text { Periode }} \times 100 \%
$$

2) Proses Operasi

$$
\text { Operasi }=\frac{\text { Jumlah Peningkatan Operasi pada } 1 \text { periode }}{\text { Target operasi pada } 1 \text { periode }} \times 100 \%
$$

\section{d) Prespektif Learning and Growth}

1) Retensi Karyawan

$$
\text { Rumus }=\frac{\text { Jumlah Karyawan keluar per periode }}{\text { Julah total Karyawan }} \times 100 \%
$$

2) Produktivitas karyawan

$$
\text { Rumus }=\frac{\text { Peningkatan penerimaan dana Zakat }}{\text { Jumlah total Karyawan }} \times 100 \%
$$

3)Peningkatan kepuasan Karyawan

Untuk mengetahui tingkat kepuasan Karyawan dengan Wawancara kepada karyawan BASNAZ Sragen yang terdiri dari 5 Pegawai.

4. Metode Analisis Data

Adapun metode yang digunakan adalah metode kualitatif deskriptif eksploratif, Penelitian berupa studi kasus. Dilakukan dengan cara:

a. Memaparkan dan menjelaskan data-data yang telah didapatkan, seperti data keuangan BAZNAS, laporan kinerja BAZNAS dan data personel/karyawan dan Muzakki, untuk kemudian diolah menjadi pemacu ukuran kinerja.

b. Memberikan skor untuk masingmasing pemacu kinerja berdasarkan empat perspektif Balanced Scorecard.

Tabel Rating Scale

\begin{tabular}{|c|c|}
\hline Skor & Nilai \\
\hline-1 & Kurang \\
\hline 0 & Cukup \\
\hline
\end{tabular}




\begin{tabular}{|c|c|}
\hline 1 & Baik \\
\hline
\end{tabular}

c. Menentukan kriteria kinerja "kurang”, "cukup", dan "baik" dengan membuat skala penilaian kinerja balanced scorecard dari hasil pemberian skor pada masing-masing indikator. Kinerja dikatakan "kurang" jika besar nilainya kurang dari 50\% (skor 0). Kinerja dikatakan "baik" apabila lebih dari $80 \%$ dan diasumsikan bahwa 80\% sama dengan 0,6. Sisanya adalah daerah "cukup", yaitu antara 0-0,6.

d. Skor yang didapat dari masingmasing pengukuran baik berdasarkan standar BAZNAS maupun Balanced Scorecard, kemudian dibandingkan. Pengukuran dengan skor lebih besar menunjukkan tingkat ketepatan yang lebih baik. Hal ini berguna untuk mengetahui, apakah kinerja BAZNAS selama ini sudah baik menurut prespektif Balanced Scorecard.

\section{Hasil Penelitian}

Setelah menganalisa kinerja BAZNAS Sragen dengan menggunakan Balanced Scorecard, didapatkan hasil sebagai berikut:

\begin{tabular}{|l|c|c|}
\hline \multicolumn{1}{|c|}{ Prespektif } & Hasil & Score \\
\hline Keuangan & 102,06 & 1 \\
\hline Konsumen & 0 & -1 \\
\hline Kemampuan memperoleh Muzakki baru & 100 & 1 \\
\hline Kemampuan Mempertahankan Muzakki & 5078 & 1 \\
\hline Tingkat Kepuasan Pelanggan & 93,61 & 1 \\
\hline Bisnis Internal & 100 & 1 \\
\hline Inovasi & \multicolumn{2}{|c|}{} \\
\hline Proses Bisnis Internal &
\end{tabular}




\begin{tabular}{|l|c|c|}
\hline Pembelajaran dan Pertumbuhan \\
\hline Produktifitas Karyawan & 1.115 .378 .884 & 1 \\
\hline Tingkat Kepuasan Karyawan & $75-80$ & 1 \\
\hline \multicolumn{2}{|c|}{ Total } & 6 \\
\hline
\end{tabular}

Sumber; Hasil analisis data

Setelah dilakukan penelitian maka diperoleh hasil bahwa, kinerja BAZNAS Kab Sragen dinilai "Baik". Dengan hasil sebagai berikut: 1) Prespektif Keuangan mendapat skor 1(baik), 2) Prespektif Konsumen dari akuisi pelanggan mendapat skor -1(kurang), dan dari retensi pelanggan mendapatkan skor 1(baik), dan dari kepuasan konsumen mendapatkan skor 1(baik). 3) Prespektif Bisnis Internal dari Inovasi mendapat skor 1(baik), dan dari proses operasi mendapat skor 1(baik). 4) Prespektif Pembelajaran dan Pertumbuhan dari produktifitas karyawan mendapat skor 1(baik), dan dari kepuasan kerja karyawan mendapat skor nilai 1(baik). hasil skor rata-rata penilaian kinerja BAZNAS Kab Sragen adalah $6: 8=\mathbf{0 , 7 5}$ yaitu "Baik".

\section{E. Kesimpulan}

Dari hasil penelitian, didapatkan bahwasannya Kinerja BAZNAS Sragen dinilai dengan menggunakan Balanced Scorecard adalah "Baik", dengan prosetase 0,75 . Artinya BAZNAS Sragen harus terus berusaha memperbaiki dan meningkatkan kinerjanya supaya semakin optimal dan bermanfaat bagi masyarakat banyak.

\section{DAFTAR PUSTAKA}

Achya Zaenul Huda, Analisis Kinerja dengan pendekatan Pendekatan Balance Scorecard (Studi kasus pdam Tirta Dharma Kabupaten Klaten), (Skripsi Fakultas Ekonomi dan Bisni Universitas Muhammadiyah Surakarta 2013)

Endang Kiswara SE., M.Si., Akt., Analisis Balance Scorecard Sebagai Alat Pengukur Kinerja Perusahaan (Studi Kasus pada PT Astra Honda Motor)

Hendri tanjung dan abrista devi, Metode Peneltian Ekonomi Islam, (Jakarta: Gratama Publishing 2013)

http://mysharing.co/baz-sragen-himpundana-zakat-rp-250-juta-per-bulan/ , Saturday, 4 June 2016. Diunggah pada 3:00 WIB. 
http://mysharing.co/baz-sragen-himpun-

dana-zakat-rp-250-juta-per-bulan/

, Saturday, 4 June 2016. Diunggah pada 3:00 WIB.

Isniar Budiarti, Balanced Scorecard Sebagai Alat Ukur Kinerja Dan Alat Pengendali Sistem Manajemen Strategis, (jurnal majalah ilmiah Unikom, Vol 6 Universitas Komputer Indonesia Program studi Manajemen).

M.Nur Rianto, Lembaga Keuangan Syari'ah, (Bandung : Pustaka Setia 2012)

Mahmudi, manajemen kinerja sector public, (Yogyakarta, UPP STIM YKPN : 2010)

Monika Kussetya Ciptani, Balanced Scorecard Sebagai Pengukuran Kinerja Masa Depan: Suatu Pengantar, (Jurnal Akuntansi \& Keuangan Vol. 2, No. 1, Mei 2000)

Mulyadi, Sistem terpadu pengelolaan kinerja personel berbasis Balanced Scorecard, (Yogyakarta, UPP STIM YKPN : 2009)

Seviawati polinggapo, Pengukuran Kinerja Lembaga pengelola
Zakat, Infaq san sedekah (ZIS) dengan menggunakan metode Balanced Scorecard (Studi kasus pada Yayasan Dana Sosial AlFalah Malang), (jurnal akutansi Fakultas Ekonomi UIN Maliki Malang)

Utami Puji Lestari, Balanced Scorecard (Bsc) Sebagai Alat Pengukur Kinerja Manajemen Dalam Pengembangan Strategi Perusahaan, (jurnal Ebis, Volume 6 Nomor 2 Juli 2014)

Zakkaaha, Jurnal BAZNAS kabupaten Sragen, Sedekah dari masa ke masa, edisi 4 Vol 1 April 2015 